\author{
Geology and geophysics
}

http://www.journalesgia.com

\title{
DANGEROUS ATMOSPHERIC EVENTS: A NEW PHYSICAL-MATHEMATICAL APPROACH
}

\author{
Arsen'yev S.A. ${ }^{1}$, Eppelbaum L.V. ${ }^{2}$, Ermakov N.N. ${ }^{3}$ \\ ${ }^{1}$ Dept. of Earth and Planetary Physics of Schmidt's Institute of the Earth's Physics, \\ Russian Academy of Sciences \\ 10 Bolshaya Gruzinskaya str., Moscow, Russia, 123995: Arsy7@mail.ru \\ ${ }^{2}$ School of Geosciences, Raymond and Beverly Sackler Faculty of Exact Sciences. Tel Aviv University \\ Ramat Aviv, 6997801, Tel Aviv, Israel: levap@post.tau.ac.il \\ ${ }^{3}$ School of Chemistry, Raymond and Beverly Sackler Faculty of Exact Sciences. Tel Aviv University \\ Ramat Aviv, 6997801, Tel Aviv, Israel: ermakov@post.tau.ac.il
}

Keywords: tornado, long tide gravity waves, Earth-MoonSun gravity system, soliton, dangerous environmental phenomena

Summary. A significant progress has been recently reached in a long-range forecast of such dangerous atmospheric events as catastrophic and violent tornadoes (EF3-EF5 level). Eppelbaum (2013) elaborated non-stochastic long-term prediction method using pattern recognition theory and Fourier analysis. He detected a close correlation tie of the total tornado numbers per annum with the gravity system of the Earth - Moon - Sun producing the tide forces. However, physical meaning of this effect leaves undisclosed. In present work, we propose a physical-mathematical model which elucidates the process of violent tornado initiation. It occurs in two main stages. At first, the gravitational forces and the hurricane winds in the upper troposphere form the long tide non-linear waves in the lower troposphere. The gale-force winds in the top troposphere arise at intrusion of air cold masses into the warm areas and are usually connected to the fast synoptic cyclones bearing thundery cloudiness and rains. The arisen gravitational non-linear waves rush at the speed of tide waves $V=(g H)^{1 / 2}$ along the subcloud inversion. After this, gravitational waves fall on (and it is absorbed into) thunderstorm supercells which are already formed inside the cold atmospheric front. In the result of the meteorological field adaption, a pressure inside the thunderstorm supercells decreases, wind rotation becomes stronger and generates a violent tornado. Various environmental examples illustrate an applicability of the developed approach. The theoretical results show a good agreement with the field observations. The proposed new physical-mathematical methodology can be conceptually applied to analysis of other environmental phenomena.

(C) 2019 Earth Science Division, Azerbaijan National Academy of Sciences. All rights reserved.

\section{Introduction}

Dangerous atmospheric events produce annual damage of many dozens billion US \$ only in the USA (Smith and Katz, 2013; Eppelbaum and Isakov, 2015). Tornadoes are the natural processes of the highest possible intensity in the atmosphere. Velocity of wind in the violent tornadoes exceeds $516 \mathrm{~km} /$ hour; therefore they generate great destructive forces. In scientific literature (e.g., Nalivkin, 1969) are given many examples of the total destruction of small towns by tornado. Therefore, the problem of their analysis is high actual (e.g., Doswell and Burgess, 1993; Arsen'yev et al., 2000, 2001, 2004; 2010; Marshall, 2002; Drton et al., 2003; Hirth et al., 2008; Garner, 2012; Naylor and Gil- more, 2012; Wurman et al., 2012; Eppelbaum, 2013; Eppelbaum and Isakov, 2015; Markowski and Richardson, 2014; Laing, 2015; Huang et al., 2016; Paulikas and Schmidlin, 2017).

An influence of solar activity and Moon and Sun gravity fields on many Earth's processes is wellknown (e.g., Chizevsky, 1976; Arsen'yev, 1995, 1998; Gadirov, 2001; Sidorenkov, 2002; Belyakov et al., 2008; Scafetta and West, 2008; Gray et al., 2012; Alizadeh et al., 2017) and is studied by physical, statistical, probabilistic and analytical approaches. The Moon-Sun gravity fields, besides atmospheric phenomena, influence to the spread of epidemics and the productivity of many crops (e.g., Chizevsky, 1976), mud volcanism (e.g., Alizadeh et al., 2017), 
earthquake triggering (e.g., Tanaka et al., 2004), driving plate tectonics (e.g., Riguzzi et al., 2010) and to many other analyzed and do not investigated yet effects.

The most popular methodology for modelling the catastrophic weather phenomena (tornado, hurricanes, strong wind) are: (a) the statistical approach based on the probability density function, and (b) the deterministic approach, basing on the numerical solution the differential equations of the atmospheresocean dynamics. Representation about modern statistical methods of the tornado forecast can be obtained from articles: Eppelbaum (2013), Eppelbaum and Isakov (2015) where reviews of the basic works development in the given direction were presented. In particular, Eppelbaum (2013) has developed a method for the forecast of number of tornado per year, using the historical data of tornado observation in the USA during 63 years, from 1950 to 2012. In the analysis of these data he revealed the maxima (initial harmonics) in spectra of tornado which coincide with the factors describing the tidal gravity forces of the Moon and Sun (a simplified scheme of the Earth-Moon-Sun interaction is presented in Figure 1). The maximum of 2.9 years coincides with the Moon's resonance period. It is the minimal period which can be caught in a spectrum because NyquistKotelnikov's period (Nyquist, 1928; Kotelnikov, 1933 ) in our case is equal to two years, and the period of digitization is equal to one year. The maximum of 18.6 years corresponds to the Moon's nodal period. A spectrum of number of tornado per year has also a second harmonic of the Moon's nodal period of 9.3 years. The maximum of 63 years is near to the maximum of 64 years which corresponds to the long-period part of the Moon's gravity field variations. In the tornado spectra there is also a peak 4.2 years which corresponds to the Sun activity. It determines the duration of the rise from the minimum to maximum number of sunspots during of Sun activity (e.g., de Jager, 1959; Landscheidt, 1995, 2013). Thus, time changes in gravity fields of the Sun - Moon - Earth system is connected with the interannual variability of tornado series. Statistical methods though allow predicting number of tornado per year; however do not describe the physical mechanism of the tornado activity relative to the gravity fields of the celestial bodies. To clarify "how it works", we should attract the models of tornado based on solutions of the equations of geophysical hydrodynamics.

Arsen'yev et al. (2010) were done a review of the modern numerical models allowing to calculating the structure of tornado. A lot of models reproducing existential evolution and internal structure of the weak (EF0-EF1) and strong (EF2-EF3) torna- does was developed. Their common shortcoming is the simplified description of the turbulence effect with two scales utilization. The basic scale corresponds to an average wind velocity in tornado. Other stochastic, minor scale describes the small-scale turbulence. It provides the energy dissipation and reduces average velocity of a wind in tornado.

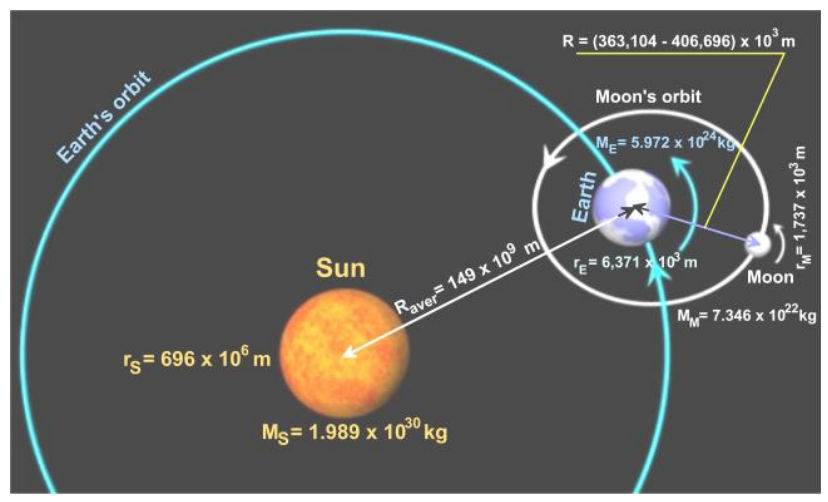

Figure 1. A simplified scheme (not to scale) of the Sun-MoonEarth interaction with their masses (M) and distances (R) between the Sun and Earth and Moon and Earth and radiuses (r). Subscripts S, E and M denote Sun, Earth and Moon, respectively (after Eppelbaum, 2019)

However, Lorenz (1953) has shown on an example of two-dimensional model that the basic average current is stable, if all lengths of waves of the turbulent disturbances in a flow are less than the length of a wave of the basic current (i.e., a spectrum of the basic current and small-scale turbulence are not overlap). Nevertheless, if in turbulent current there are longer components, for example, convective jets and cells, thermic bubbles, vortical rollers, internal waves, coherent and other eddies, then spectrum of the basic and turbulent current have the common zone, which is filled by mesoscale eddies. In this case the basic current may be unstable and it can increase in time, due to the nonlinear interaction with the mesoscale eddies (Kardashov and Eppelbaum, 2008). The theory of the mesoscale turbulence stated in Arsen'yev et al. (2010) and Nikolaevskiy (2003) allows taking into account in an explicit form the presence of the third intermediate mesoscale in a spectrum of atmospheric currents. Application of this theory to problems of calculation of tornado and tropical hurricanes has allowed to obtain the violent tornadoes (EF4-EF5) and super typhoons due to amplification of the average wind getting energy from the mesoscale eddies (Arsen'yev et al., 2004, 2010). Classification of the mesoscale eddies is presented in Arsen'yev et al. (2010). These eddies fill thunderstorm supercell generating tornado, or arise from the superheated ocean surface producing tropical hurricanes. Instability and growth of the average current arise from 
performance of the special conditions which are established by the theory of the mesoscale turbulence. The energy and angular velocity of the mesoscale eddies should be sufficiently large.

Different mechanism for amplification of the weak rotatory tornadogenesis thunderstorm supercell is the superposition of an average wind inside this supercell and the long tidal gravitational wave in the troposphere attacking the supercell.

This investigation is an evaluation of some basis ideas on the tornado mathematical modeling presented earlier in Arsen'yev (2011).

\section{Long non-linear tide waves in troposphere}

Kardashov et al. (2000) and Eppelbaum and Kardashov (2001) have shown that the majority of geological, geophysical and environmental processes in the Earth are characterized by nonlinear behavior. Let us consider the typical distribution of the temperature $T$ in the Earth's troposphere (Figure 2).

A characteristic feature of the squall storms is the presence of clouds which have a thin inversion layer at the bottom boundary. Within this inversion, the temperature increases with altitude, but above and below this phenomenon the temperature decreases (Figure 2). An inversion arises at a condensation level, slightly above the bottom boundary of the clouds, because inside the cloud the temperature increases due to emission of the latent heat of vaporization (obviously, this process has a nonlinear character). It is essential that the inversion has disabling features which make it stable. The volume of air ascending from below the inversion is colder than the surrounding air and is pushed downward by the Archimedes forces. Similarly, warmer air, which enters the inversion from the top, is pushed upward. This allows us to simulate the inversion by a streamline $\zeta(x, y)$ surface. Here, horizontal wind velocities $u$ and $v$ may exist, and the vertical velocity $w$ satisfies to the impermeability condition:

$$
\text { when } z=\varsigma, w=\frac{\partial \varsigma}{\partial t}+u \frac{\partial \varsigma}{\partial x}+v \frac{\partial \varsigma}{\partial y} \text {. }
$$

In addition, the vertical turbulent stresses in the inversion must be continuous

$$
\text { when } z=\varsigma, \mathfrak{R}_{x}^{z}=\mathfrak{R}_{x}^{0}, \mathfrak{R}_{y}^{z}=\mathfrak{R}_{y}^{0} \text {. }
$$

Here $\mathfrak{R}_{x}^{z}$ and $\mathfrak{R}_{y}^{z}$ are the turbulent tensions at the lower boundary layer of atmosphere (LBLA), $\mathfrak{R}_{x}^{0}$ and $\mathfrak{R}_{y}^{0}$ are the turbulent tensions at the lower boundary of the middle troposphere (MT), $\zeta$ is the disturbance level of the inversion surface, $z$-axis is directed downward from the unperturbed level of $z=0$, Earth's surface (ES) is at the level of $z=H$ (Figure 2).

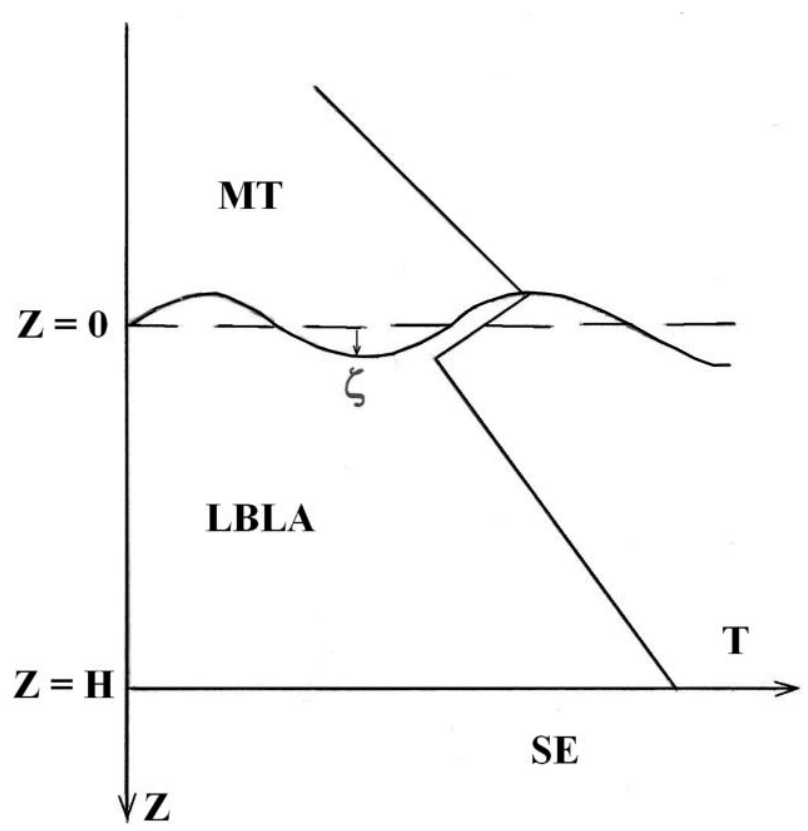

Figure 2. System of coordinates and temperature of air in the lower boundary layer of atmosphere (LBLA) and in the middle troposphere (MT). Position of the inversion layer is denoted by line $\zeta$, letters SE designate the surface of the Earth (SE)

If the inversion in any area is destroyed by powerful movement upward, then condition (1) does not hold and the air gathers to the spots forming powerful thunderstorm $\mathrm{Cb}$ clouds (Snow, 1984). However, if the vertical motions are insufficient to break the inversion and condition (1) takes place, then and gravity waves arise on the inversion surface. The problem of studying these waves on the surface with different temperatures and velocities for the first time was set in the $19^{\text {th }}$ century by Kelvin and Helmholtz (Lamb, 1945). The complete solution of this problem, which takes into account the compressibility of air and temperature variability, was obtained by D.L.Laikhman in 1947 (Khrgian, 1978). This solution describes internal waves in the troposphere. However, the fundamental mode, corresponding to gravity waves in the atmosphere with a uniform density, is omitted in this solution. This mode appears in the analysis of the Laplace tidal equations in atmosphere (Dikiy, 1969). It should be noted that a consideration of the movements in the lower atmospheric boundary layer associated with this mode is practically important. In present paper, this problem is solved for the long gravity waves, for which takes place the static condition

$$
g p=\frac{\partial p}{\partial z}
$$


For these waves the wavelength $\lambda$ much greater than the thickness $H(\lambda>>H)$. Thus, we use the theory of shallow water, which is created in geophysical hydrodynamics for analysis of long waves in particular tides (Gill, 1982; Pedlosky, 1992).

The density $\rho$ and pressure of air $p$ which are included in Eq. (3) change with the altitude. To determine these changes, we use the following equation

$$
p=R_{c} \rho T,
$$

where $R_{c}=287 \mathrm{M}^{2} / \mathrm{c}^{2}$ and ${ }^{0} \mathrm{~K}$ is the specific gas constant of the dry air.

The effects of humidity are not important in the LBLA at altitudes below the level of condensation, which practically coincides with the level of $z=$ 0 (Figure 2). Since we are interested in the movement within the LBLA at $z \geq \zeta$, an influence of humidity can be neglected. Let us take the logarithm of Eq. (4) and take the derivative of the result with respect to $z$. We obtain

$$
\frac{1}{p} \frac{d p}{d z}=\frac{1}{\rho} \frac{d \rho}{d z}+\frac{1}{T} \frac{d T}{d z} .
$$

Substituting pressure $p$ in Eq. (5) from Eq. (4) and the gradient $\mathrm{d} p / \mathrm{d} z$ from Eq. (3), we find

$$
\frac{g}{T R_{C}}=\frac{1}{\rho} \frac{d \rho}{d z}+\frac{1}{T} \frac{d T}{d z} .
$$

Thus, we find the law defining the change of density with altitude

$$
\frac{1}{\rho} \frac{d \rho}{d z}=\frac{1}{T}\left(\gamma_{0}-\gamma\right)
$$

where $\gamma=\frac{d T}{d z}$ and $\gamma_{0}=\frac{g}{R_{c}}=3.42 \cdot 10^{-2}{ }^{\circ} \mathrm{C} / \mathrm{m}$ is a constant. It is temperature gradient in a uniform density atmosphere, because on assumption $\gamma_{0}=\gamma, \frac{\partial \rho}{\partial z}=0$.

If $\gamma>\gamma_{0}$, then the air density increases with altitude since $d \rho / d z<0$. This situation is practically rare. It may occur during intense heating of the LBLA in the day time in the summer and corresponds to an unstable state of atmosphere, because the heavy air is at the top, the light air is at the bottom, and $\gamma>\gamma_{0}>\gamma_{a}$, where $\gamma_{a}=10^{-2}{ }^{0} \mathrm{C} / \mathrm{m}$ is the dry-adiabatic temperature gradient. Upon cooling of the lower atmospheric boundary layer in the stormy weather, we have the condition $\gamma \cong \gamma_{0}$, which corresponds to a uniform density atmosphere. The case $\gamma>\gamma_{0}$, where the air density decreases with altitude is the most frequent one (conventional) and is observed above the LBLA in the middle troposphere $(M T)$. This corresponds to the stable stratification where heavy air is on the bottom (Arsen'yev, 2011). Thus, we will consider the case $\gamma \cong \gamma_{0}$, in which the stratification inside the LBLA is unstable $\left(\gamma_{0}>\gamma_{a}\right)$. This means that the air inside the LBLA is mixed by turbulent convection and turbulence generated by the vertical shear of the mean wind velocity.

The condition $\rho=$ const allows us to vertically integrate Eq. (3) from $z=\zeta$ до $z$ and to obtain the law of the air pressure changing versus height inside the LBLA

$$
p=p_{0}+g \rho(z-\zeta)
$$

where $p_{0}$ is the pressure at the level of $z=\zeta$.

Let us direct the $x$-axis along the wind current at the lower boundary of the middle troposphere $M T$ and denote the wind velocity at this boundary by the letter $W$. Strong winds within the middle troposphere $M T$ tend to quadratic law of resistance in the inversion. That is, if $z=\zeta$

$$
\mathfrak{R}_{0}^{x}=C_{g} W^{2},
$$

where $C_{g}$ is the coefficient of a resistance.

In Eqs. (2) and (8) the tangential wind stress is divided by the air density $\left(\rho=1.3 \mathrm{~kg} / \mathrm{m}^{3}\right)$. This means that we consider the kinematic (referred to the average density of air) tangential wind stress. Flows within the LBLA that emerge under the influence of the wind $W$ are also directed along the $x$ axis, since we neglect the Coriolis force due to not large thickness of the LBLA. Therefore, cross currents along the $y$-axis are irrelevant, and we may write the equations of motion and continuity in the form of

$$
\begin{aligned}
& \frac{\partial u}{\partial t}=-\frac{1}{\rho} \frac{\partial p}{\partial x}-\frac{\partial \Re_{x}^{z}}{\partial z}+A_{L} \frac{\partial^{2} u}{\partial x^{2}}, \\
& \frac{\partial u}{\partial z}+\frac{\partial w}{\partial z}=0,
\end{aligned}
$$

where $A_{L}$ is the coefficient of the horizontal shear turbulent viscosity.

Eqs. (9) and (10) contain the turbulent tensions and vertical velocities $w$ inside the LBLA. We can eliminate these factors by the vertical integration from $z=\zeta$ to $z=H$. As a result, Eq. (10) will have the following form:

$$
\frac{\partial \varsigma}{\partial t}=\frac{\partial S}{\partial x}
$$

where $S=\int_{\zeta}^{H} u d z$ is the total vertical flow. 
In deriving Eq. (11) we take into account the boundary conditions (1), (2) and condition at the Earth's surface $E S$

$$
\text { when } z=H, \quad u=w=0 .
$$

It is easy to exclude the pressure $p$ from Eq. (9) using the law (7)

$$
\frac{1}{\rho} \frac{\partial p}{\partial x}=\frac{1}{\rho} \frac{\partial p^{0}}{\partial x}-g \frac{\partial \varsigma}{\partial x}
$$

It is convenient to present the level of inversion $\zeta$ as the sum of the statical $\zeta_{s}$ and the dynamical $\zeta_{d}$ components: $\zeta=\zeta_{s}+\zeta_{d}$. Then, if the statical tilts of the inversion level are balanced by pressure gradients on the inversion

$$
\frac{1}{\rho} \frac{\partial p_{0}}{\partial x}=g \frac{\partial \varsigma_{S}}{\partial x}
$$

then Eq. (13) may be written as

$$
\frac{1}{\rho} \frac{\partial p}{\partial x}=-g \frac{\partial \varsigma_{d}}{\partial x}
$$

Substituting Eq. (14) into Eq. (9) and omitting the index $d$ (hereinafter we consider only the dynamics tilts of the level $\zeta_{d}$ ) we find

$$
\frac{\partial u}{\partial t}=g \frac{\partial \varsigma}{\partial x}-\frac{\partial \Re_{x}^{z}}{\partial z}+A_{L} \frac{\partial^{2} u}{\partial x^{2}}
$$

Let us integrate Eq. (15) by $z$ in the LBLA. We obtain

$$
\frac{\partial S}{\partial t}=g H \frac{\partial \zeta}{\partial x}-\mathfrak{R}_{x}^{H}+\mathfrak{R}_{x}^{0}+A_{L} \frac{\partial^{2} S}{\partial x^{2}} .
$$

A system of Eqs. (16) and (11) is closed one with regard to the unknown parameters $S$ and $\zeta$, if the turbulent stresses are known on the upper and lower boundaries of the LBLA or their relationship with $S$ or $\zeta$.

\section{Problem solution}

Let us find the solution of Eqs. (11) and (16) in the form of a progressive wave traveling with velocity $V: S=F(x-V t)$. Then Eq. (11) gives the algebraic relationship between $S$ and $\zeta$. Denoting $\chi=x-V t$, we get (index $\chi$ with $F$ denotes derivative by $\chi$ )

$$
\frac{\partial S}{\partial x}=F_{\chi} ; \frac{\partial S}{\partial t}=-V F_{\chi} ; \frac{\partial \varsigma}{\partial t}=\frac{\partial S}{\partial x}=F_{\chi}=-\frac{1}{V} \frac{\partial S}{\partial t}=-\frac{\partial}{\partial t}\left(\frac{S}{V}\right) .
$$

Integrating over time $t$, we obtain

$$
S=-\zeta V,
$$

because the integration constant is equal to zero (when $S=0$ and $\zeta=0$ ). Eq. (17) allows us to eliminate the level $\zeta$ from Eq. (16):

$$
\frac{\partial S}{\partial t}=-\left(\frac{g H}{V}\right) \frac{\partial S}{\partial x}-\mathfrak{R}_{x}^{H}+\mathfrak{R}_{x}^{0}+A_{L} \frac{\partial^{2} S}{\partial x^{2}} .
$$

For the friction stress at the lower boundary of the LBLA, we may use the law that is well known in the theory of long waves (Gill, 1988; Arsen'yev, 1989)

$$
\mathfrak{R}_{x}^{H}=\omega_{f} S
$$

Here $\omega_{f}$ is the frequency of friction which may be estimated with the help of following formula (Arsen'yev, 1989)

$$
\omega_{f}=\frac{3 A}{H^{2}(1-n)^{2}},
$$

where $n=z_{0} / H, z_{0}$ is the height of the roughness on the Earth's surface and $A$ is the coefficient of the vertical shear turbulent viscosity. On the other hand, the frictional stress at the upper boundary of LBLA is determined by Eq. (8). In this formula, the following relation may connect the wind velocity $\mathrm{W}$ at the lower boundary MT with the wind velocity at the upper boundary $\mathrm{u}^{0}$ of the LBLA

$$
u^{0}=k W,
$$

where $k$ is the wind coefficient. If the jump on a passage of the wind velocity through the inversion is absent, then $k=1$. Otherwise, $0<k<1$, because the wind velocity decreases with the altitude decreasing.

The total flow $S$ may be expresses through the wind velocity $u^{0}$, if we use the shallow water theory, which well describes long waves (Gill, 1982; Pedlosky, 1992). In this theory all parts of long wave are moving with the same velocity $u^{0}=u$, except for a thin near-ground atmospheric boundary layer with a thickness approximately $10 \mathrm{~m}$, where the wind velocity decreases rapidly to zero. In this case the friction is concentrated near the level $z=H$ and the relation (19) has a place. For the model of long wave $S=$ $u H$, and Eq. (8) may be written in the following form

$$
\mathfrak{R}_{x}^{0}=\left(\frac{C_{g}}{k^{2} H^{2}}\right) S^{2} .
$$


Substituting Eqs. (22) and (19) to Eq. (18) we ob- Thus, tain an equation for the parameter $S$

$$
\frac{\partial S}{\partial t}=-\left(\frac{g H}{V}\right) \frac{\partial S}{\partial x}-\omega_{f} S+\alpha S^{2}+A_{L} \frac{\partial^{2} S}{\partial x^{2}},
$$

where $\alpha=\frac{C_{g}}{k^{2} H^{2}}$.

At the same time, we should underline that we find a solution in the form of progressing wave $S=F(\chi)$.

Then $\frac{\partial S}{\partial t}=V F_{\chi}, \frac{\partial S}{\partial x}=F_{\chi}, \frac{\partial^{2} S}{\partial x^{2}}=F_{\chi x}$, and Eq.

takes the form

$$
A_{L} F_{\chi \chi}+\alpha F^{2}-\omega_{f} F+V\left(1-\frac{g H}{V^{2}}\right) F_{\chi}=0
$$

The studied tidal gravitational waves propagate with the Lagrange velocity $V=(g H)^{1 / 2}$. Hence Eq. (24) may be transformed as

$$
A_{L} F_{\chi \chi}+\alpha F^{2}-\omega_{f} F=0
$$

Eq. (25) is easy to solve by $F_{\chi}$ multiplication. In this case

$$
\frac{A_{L}}{2} \frac{d}{d \chi}\left[\left(\frac{d F}{d \chi}\right)^{2}\right]+\frac{\alpha}{3} \frac{d F^{3}}{d \chi}-\frac{\omega_{f}}{2} \frac{d F^{2}}{d \chi}=0
$$

From here, by integrating, we find

$$
\left(\sqrt{\frac{3 A_{L}}{2 \alpha}}\right) F_{\chi}=F \sqrt{\beta-F},
$$

where $\beta=\frac{3}{2} \frac{w_{f}}{\alpha}$. The constant of integration is equal to zero, because $F \rightarrow 0, F_{\chi} \rightarrow 0$ if $\chi \rightarrow \infty$.

In Eq. (27) variables are separated

$$
\frac{d F}{F \sqrt{\beta-F}}=d \chi \sqrt{\frac{2 \alpha}{3 A_{L}}} .
$$

Hence, again integrating, we obtain

$$
-\frac{2}{\sqrt{\beta}} \operatorname{arcth}\left(\sqrt{\frac{\beta-F}{\beta}}\right)=\chi \sqrt{\frac{2 \alpha}{3 A_{L}}}
$$

or

$$
\sqrt{\frac{\beta-F}{\beta}}=-\operatorname{th}\left(\chi \sqrt{\frac{\alpha \beta}{6 A_{L}}}\right) .
$$

The identity $\tanh ^{2} x \equiv 1-\operatorname{sech}^{2} x$ is true. Consequently,

$$
\frac{\beta-F}{\beta}=1-\operatorname{sech}^{2} \chi \sqrt{\frac{\beta \alpha}{6 A_{L}}} .
$$

$$
\begin{gathered}
S=F=\beta \operatorname{sech}^{2}\left(\frac{\chi}{\Delta}\right), \\
u=\left(\frac{\beta}{H}\right) \operatorname{sech}^{2}\left(\frac{\chi}{\Delta}\right), \\
\zeta=\left[\frac{\beta}{(g H)^{1 / 2}}\right]=\beta \operatorname{sech}^{2}\left(\frac{\chi}{\Delta}\right) .
\end{gathered}
$$

Here

$$
\Delta=\sqrt{\frac{4 A_{L}}{\omega_{f}}}=H(1-n) \sqrt{\frac{4 A_{L}}{3 A}} .
$$

is the wide of solitons (29) - (32).

It should be noted that importance of applications of such mathematical models as solitons in the applied and environmental geophysics was underlined in Kardashov et al. (2000).

Using solutions (7) and (31), we find changes in pressure in the LBLA

$$
p=p^{0}+g \rho z-g \rho \frac{\beta}{\sqrt{g H}} \operatorname{sech}^{2}\left(\frac{\chi}{\Delta}\right) .
$$

In particular, at the Earth's surface, when $z=H$

$$
p=p^{0}+g \rho H-g \rho \frac{\beta}{\sqrt{g H}} \operatorname{sech}^{2}\left(\frac{\chi}{\Delta}\right) .
$$

From Eqs. (30) and (34) is evident that during pass of the solitary tide wave, the pressure decreases but the wind velocity increases. Duration of the solitary tide wave may be estimated by the following formula

$$
t_{*}=\frac{\Delta}{V}=\sqrt{\frac{4 A_{L}}{g \omega_{f} H}} .
$$

As example, Figures 3 and 4 show calculation of oscillations of the surface pressure and the wind velocity with utilization of the following parameters: $C_{g}=10^{-2}, k=0.7, H=980 \mathrm{~m}, p_{0}=888.4 \mathrm{GPa}, g=$ $9.8 \mathrm{~m} / \mathrm{s}^{2}, \rho=1.3 \mathrm{~kg} / \mathrm{m}^{3}, z_{0}=0.05 \mathrm{~m}$ (grass, rye), $A=129.7 \mathrm{~m}^{2} / \mathrm{s}, A_{L}=2.16 \cdot 10^{6} \mathrm{~m}^{2} / \mathrm{s}$. In this case $\Delta=147 \cdot 10^{3} \mathrm{~m}, \beta=30380 \mathrm{~m}^{2} / \mathrm{s}, \alpha=2.08 \cdot 10^{-8}$. From Figures 4 and 5 we see that the maximal wind velocity reaches $31 \mathrm{~m} / \mathrm{s}$, and time of its passage (see Eq. (35)) is 25 minutes. The minimal pressure is equal to $973.76 \mathrm{GPa}$, and the width of the soliton is $147 \mathrm{~km}$, i.e. the solitary tide wave is the mesoscale atmospheric phenomenon that occurs during hurricane winds in the middle troposphere. In this case the maximum value of $W$ is $44.3 \mathrm{~m} / \mathrm{s}$.

The obtained solution describes a squall storms which are observed in the natural conditions. According to (Nalivkin, 1969; Khromov and Mamon- 
tova, 1974), a squall storm is short-term and strong increase in the average wind velocity without rotation in the areas of heavy storms or fast cyclones, with cloud and rain. Squall storms lead to sea disasters. For example, in March 1878, the British frigate "Eurydice" was overturned by a squall storm and almost immediately went down along with its crew. The same accident has occurred with the Russian linear ship "Mermaid" on September 19, 1893, in the Baltic Sea, 178 seamen were lost. On the land, the squall storms may destroy lightweight buildings and cause a windfall in the woods. For example, at region of Upper Volga River (nearby of the Lake Seliger, Russia) on July 29, 2017, a squall storm with the wind velocity up to $35 \mathrm{~m} / \mathrm{s}$ and duration of 20 minutes has caused the significant damage to farms. Trees were uprooted and roofs were blown away, fences were torn down, and panes of windows were broken. In San Francisco on November 21, 1910, a squall storm has attacked the fortified town houses. They remained standing but experienced a strong tremor. The duration of the storm was only $2 \mathrm{~min}$, but the wind velocity reached $100 \mathrm{~km} / \mathrm{h}$. Nalivkin $(1969$, p.148) notes that it was: «As if a huge, long, and narrow air wave flew over the city».

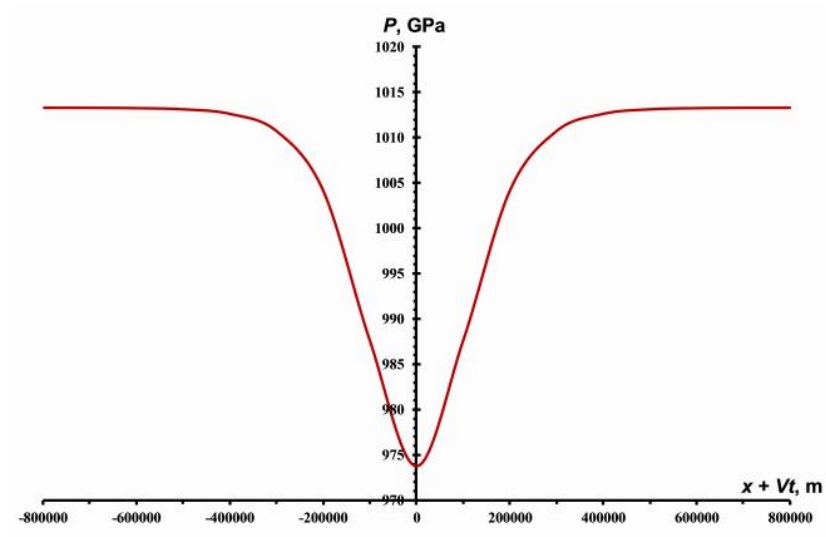

Figure 3. Calculation of the pressure at the ground $P$ during the time of the squall storm. Minimal and maximal registered pressures were 973.756, and 1013.25 GPa, respectively. Anomalous pressure difference was $34.49 \mathrm{GPa}$

Figure 5 shows an example of a real squall storm. We see as on the background of weak southwest wind a strong solitary perturbation appears in the form of the north-west wind with a maximum wind velocity of $31 \mathrm{~m} / \mathrm{s}$. The wind soliton is very narrow, but during $10 \mathrm{~min}$ the wind velocity increases from 3 to $31 \mathrm{~m} / \mathrm{s}$, and then during $15 \mathrm{~min}$ decreases to $2 \mathrm{~m} / \mathrm{s}$. The total lifetime of this storm was $t=25 \mathrm{~min}$. There was no air rotation that is typical for the whirlwinds and tornadoes. The calculated theoretical values of the maximal wind velocity and time of existence of the solitary tidal wave, excited by a gale-force wind in the middle and top troposphere, coincide with supervision. Thus, the theory explains process of the squall storms formation and gives us the method for calculation of this phenomenon.

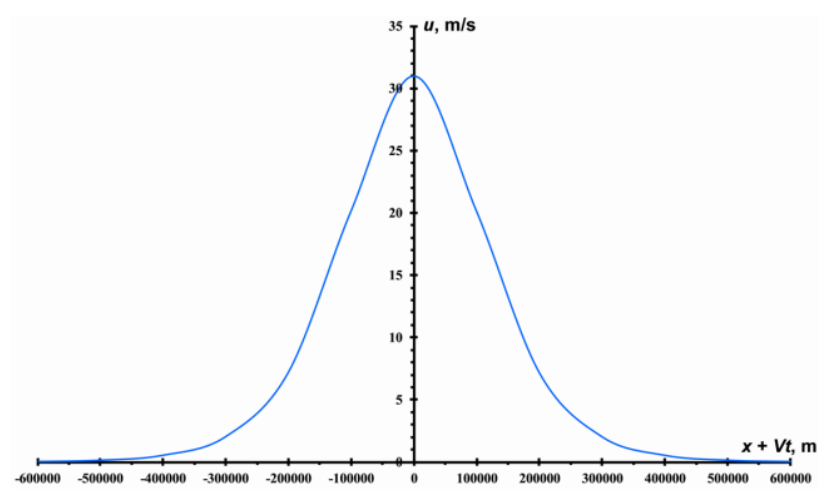

Figure 4. Calculation of the wind velocity at the ground on passage of the squall storm. The maximal wind velocity was $31 \mathrm{~m} / \mathrm{s}$
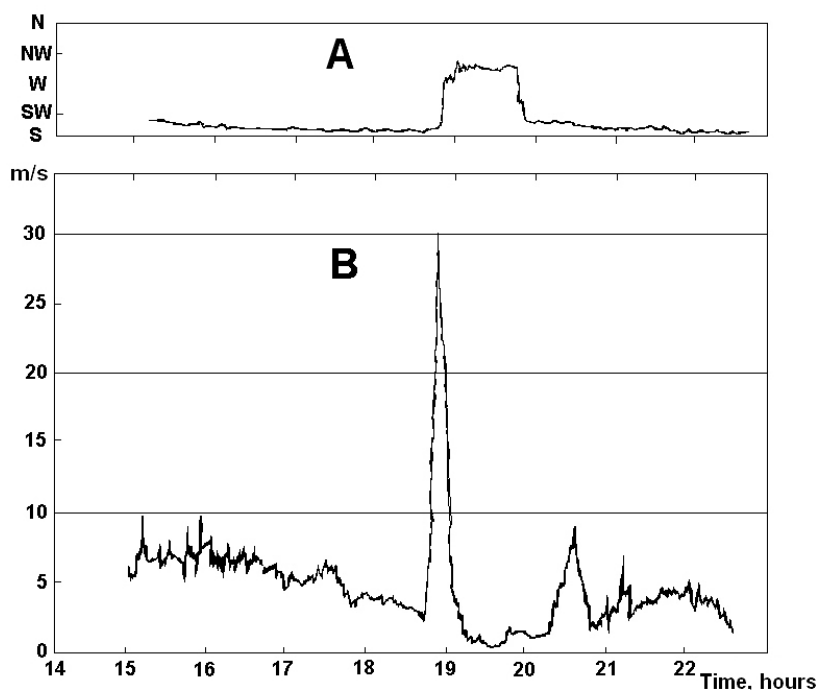

Figure 5. Observations of the wind direction (A) and wind velocity (B) during the time of the squall storm (Nalivkin, 1969, Fig. 80). The maximal wind velocity was $31 \mathrm{~m} / \mathrm{s}$

\section{Tornado appearing}

Squall storms propagate on the subcloud inversion layer. However, such inversions do not exist always. For instance, large vertical velocity caused by intensive updrafts on a cold atmospheric front, destroy theirs. But the vertical airflows generate the thunderclouds $C b$ (Snow, 1984; Arsen'yev et al., 2010; Laing, 2015). If the several slight thunderstorms are amalgamating, then one large supercell arises which may generate a tornado. Snow (1984) mentioned that this effect does not happen in $40 \%$ of all cases. However, in other cases, tornado arises inside a supercell and rapidly propagates down to the Earth's surface (e.g., Wurman et al., 2012). 
Process of tornado appearance can be presented as capture of a squall storm by the thundery supercell. Running on a surface of inversion, the squall storm falls into supercell where this inversion is destroyed. And the long wave of a squall storm remains inside a supercell because inversion here is absent. Thus, a squall storm soliton should be captured by the supercell with further adaptation of air pressure and wind velocity to each other. This mutual adaptation of the meteorological fields also results in appearance of tornado in which the wind velocity and the gradient of air pressure can reach greatest values.

Usually, the thundery supercell is weaklyrotating due to, e.g., the shear eddy instability (Arsen'yev et al., 2000, 2010). Air rotation inside a supercell is described by the cyclostrophic balance

$$
\frac{\partial p}{\partial x}=\rho \frac{v^{2}}{r},
$$

where $r$ is the radial coordinate oriented outside from the rotation center.

Capture of a storm by the thundery supercell results in pressure drop within a supercell that causes amplification of the wind rotation and produces of tornado. To find the wind velocity in tornado development, it is necessary to change $\chi$ in Eq. (34) to $r$, then to differentiate Eq. (34) with respect to $r$, and substitute the result into Eq. (36). Resolving the resulting equation with respect to the azimuthal velocity $v$, we derive the formula for the wind velocity in a developing tornado

$$
v=\operatorname{sech}\left(\frac{r}{\Delta}\right) \sqrt{\frac{2 g \beta r}{V \Delta} \operatorname{th}\left(\frac{r}{\Delta}\right)} .
$$

The surface air pressure inside the tornado is defined by the functional relation in Eq. (34).

\section{The proposed theory verification}

Physical-environmental model of tornado may be presented as a strongly rotating air column that originated in a cumulo-nimbus thundercloud and reaches the Earth's surface (Doswell and Burgess, 1993; Arsen'yev et al., 2010; Markowski and Richardson, 2014). Hurricane winds, which are typical for tornado cause serious damages. Therefore, moving tornado usually contains many different fragments of buildings, cars, trees, clods of spoil, water, and dust. This creates essential difficulties with the measurements of the physical quantities. Bluestein (1999) described the basic methods for the field study of tornadoes in the United States. He suggested that the remote metrology of wind velocity and direction with the Doppler radars (including those mounted on cars) is the most effective methodology. Another method is measurements of the wind velocity and wind direction, air temperature and pressure, humidity and electromagnetic fields with the help of self-contained portable equipment complexes mounted in the expected trajectories of the tornadoes. Figure 6 shows the air pressure measured inside a tornado on July 8, 1995 near Allison town (Texas) by scientists from the Langmuir's Laboratory at New Mexico, USA (Winn et al., 1999). The measurements were carried out with the use of a small device called a "tortoise" which was buried on the way of the tornado. It can be seen from Figure 2 that the air pressure is strongly fluctuated near the earth's surface inside a tornado, especially near the center. It can relate to many meso-eddies inside tornado (Arsen'yev et al., 2010). Nevertheless, the pressure monotonously decreases to the tornado's center after averaging these fluctuations (see squares in Figure 7). The maximal drop of the air pressure in the tornado is not large, about 50 hectoPascal. However, in according to Eq. (36), the wind velocity inside tornado is determined by the radial gradients of the pressure (but not by the pressure itself). Thus, sharp spatial variations of the air pressure inside tornado can induce a strong wind.

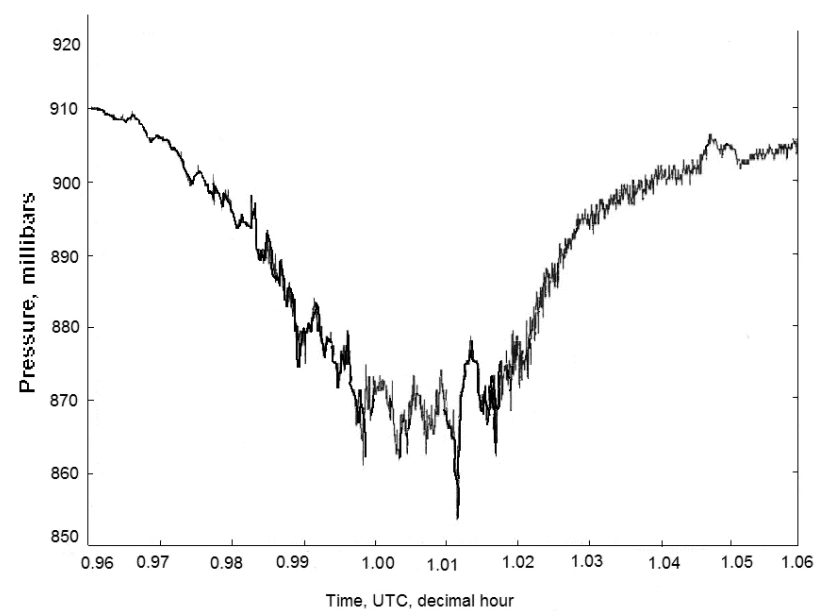

Figure 6. Metering data of the air pressure in a large tornado (after Winn et al., 1999)

The solid curve in Figure 7 shows the air pressure calculated by Eq. (34) with following parameters: $H=980 \mathrm{~m}, g=9.8 \mathrm{~m} / \mathrm{s}^{2}, V=98 \mathrm{~m} / \mathrm{s}$, $p_{0}=785.15$ hectoPascal; $\rho=1.3 \mathrm{~kg} / \mathrm{m}^{3}, A=1.7$ $\mathrm{m} / \mathrm{s}^{2}, A_{L}=67.3 \mathrm{~m} / \mathrm{s}^{2}, C_{g}=0.02, k=1, \mathrm{z}_{0}=0.05 \mathrm{~m}$ (grass, rye). The values of $\beta$ and $\Delta$ are equal to 384.6 $\mathrm{m}^{2} / \mathrm{s}$ and $7101.8 \mathrm{~m}$, respectively. For convenience, we introduce the evaluation time $t=T_{*}-3636 \mathrm{sec}-$ onds, where $T_{*}$ is the current measured time in sec shown in Figure 6. Thus, the origin of the coordinates is shifted to the point $T *=3636$ seconds $=1.01$ hour along the time axis, and the image shown in 
Figure 7 is symmetrical relative to this origin. The coincidence of the theoretical curve with the measurements results (Figure 7) confirms our theory.

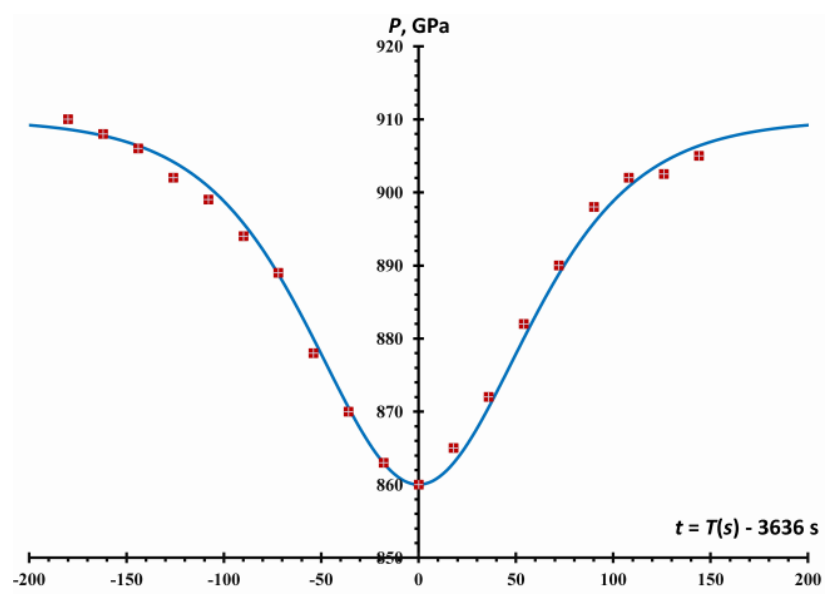

Figure 7. Theoretical computation of the air pressure in a large tornado are presented by blue solid curve. Small red squares show the averaged pressure corresponding to the observations drawn in Figure 5

To verify Eq. (37) we use the data of the Doppler radar measurements of wind velocity inside a tornado (Wurman and Gill, 2000). These data are shown in Figure 8 by squares. The solid curve in Figure 8 shows the theoretical calculations using Eq. (37) with the following parameters: $H=980 \mathrm{~m}$, $g=9.8 \mathrm{~m} / \mathrm{s}^{2}, A=300 \mathrm{~m} / \mathrm{s}^{2}, A_{L}=3.96 \mathrm{~m} / \mathrm{s}^{2}, \quad C_{g}$ $=0.02, k=1, z_{0}=0.05 \mathrm{~m}$; hence $\beta=67,500 \mathrm{~m}^{2} / \mathrm{s}$ and $\Delta=130 \mathrm{~m}$. An agreement of the theoretical calculations with measurements turned out to be worse in this case than for the air pressure calculation. Additional secondary maxima on the curve of measured wind velocity are seen in Figure 4 (at $r \approx 300 \mathrm{~m}, r \approx$ $650 \mathrm{~m}, r \approx 780 \mathrm{~m}, r \approx-500 \mathrm{~m}$, and $r \approx-780 \mathrm{~m}$ ). They are evidently connected with the large mesoscale turbulent eddies that fill the tornado. Thus, the tornado was measured at a time close to the moment of its origin, and therefore turned out to be multi-eddy. Due to this fact, the wind velocity abates much more slowly when moving away from the tornado center than it is predicted from the theory.

As is shown in (Arsen'yev et al., 2010), the mesoscale eddies inside tornado can transfer the energy to the average flow and, consequently, they decrease in size, kinetic energy, and angular momentum with a time. Therefore, we calculated the wind velocity for one more, a large powerful tornado that is close to the mature stage. The circles in Figure 9 show wind velocity measured with a Doppler radar at the height of $100 \mathrm{~m}$ in the F5-class tornado (Monastersky, 1999; Burgess et al., 2002). This violent tornado attacked Oklahoma City (USA) on May 3, 1999, damaged more than 4000 houses and 47 business buildings,
48 people died, many people received wounds of varying severities. According to Monastersky (1999), the maximum wind velocity was $144 \mathrm{~m} / \mathrm{s}(512 \mathrm{~km} / \mathrm{h}$ or $318 \mathrm{ml} / \mathrm{h}$ ). Figure 9 also shows the $10 \%$ relative error. This is unavoidable, because the measurements were carried out in uncontrollable field conditions. Figure 9 shows also the theoretical curve calculated with application of Eq. (37) under following values of parameters: $t=0, \chi=r, H=980 \mathrm{~m}, g=9.8 \mathrm{~m} / \mathrm{s}^{2}, \quad A=355,55$ $\mathrm{m} / \mathrm{s}^{2}, A_{L}=19,591.84 \mathrm{~m} / \mathrm{s}^{2}, C_{g}=0.02, k=1, \mathrm{z}_{0}=0.05$ $\mathrm{m}$, so that $\beta=80,000 \mathrm{~m}^{2} / \mathrm{s}$ and $\Delta=8,400 \mathrm{~m}$. Figure 9 indicates that the theoretical calculations and field measurements coincide within $10 \%$ accuracy.

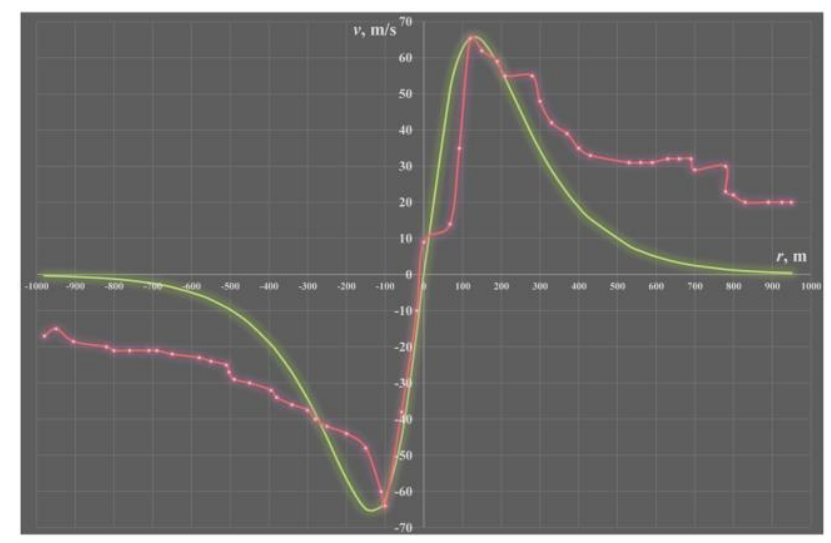

Figure 8. Comparison of the theoretical computation of the angular wind velocity $v$ in tornado (green solid curve) and physical observations of the wind velocity in tornado (red curve with white points) (last curve after Wurman and Gill, 2000)

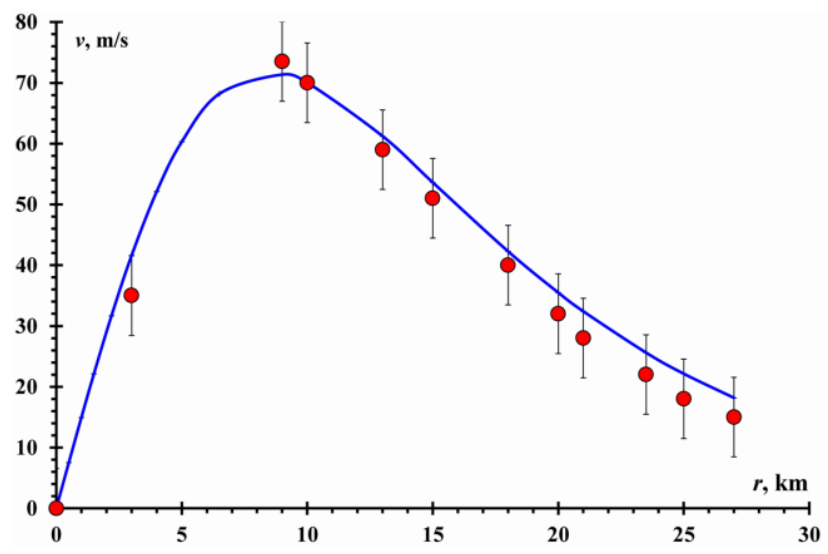

Figure 9. Comparison of theoretical computation of the angular wind velocity $v$ in tornado (blue solid line) with observations in EF5 tornado on 03 May 1999 (red circles)

\section{Analysis of obtained results and brief discussion}

A good compliance between the theoretical and measurement data indicates the applicability of Eqs. (34)-(37) for calculation of the real tornadoes. Besides the surface air pressure and wind velocity, there are other important parameters. Figure 10 demonstrates the radial distribution of vorticity in 
the F5 tornado, which corresponds to Figure 9. The calculations were done using the following expression

$$
\Omega=\operatorname{rot}_{z} v=\frac{\partial v}{\partial r}+\frac{v}{r},
$$

Here $v$ is determined by Eq. (37).

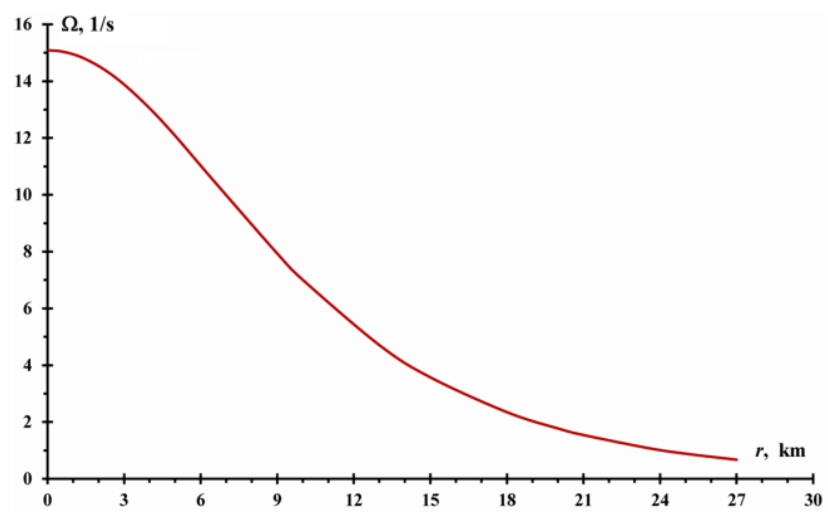

Figure 10. The radial distribution of a vorticity for the violent tornado EF5 (see Figure 8)

As it is clearly seen from Figure 10, the vorticity is maximal in the tornado center; for an EF5 tornado, it attains to a very high value of $15 \mathrm{~Hz}$. For comparison, we must note that in tropical hurricanes and typhoons $\Omega \approx 10^{-3} \mathrm{~Hz}$ (Arsen'yev et al., 2010).

Figure 11 shows the eddy force calculated for the EF5 tornado

$$
F_{E}=[v \times \operatorname{rot} v]=v \Omega=\frac{\partial}{\partial r}\left(\frac{v^{2}}{2}\right)+\frac{v^{2}}{r} .
$$

This is a sum of the dynamical thrust and the centrifugal force, which is associated with a pressure by Eq. (36)

$$
F_{E}=\frac{\partial}{\partial r}\left(\frac{v^{2}}{2}+\frac{p}{\rho}\right)
$$

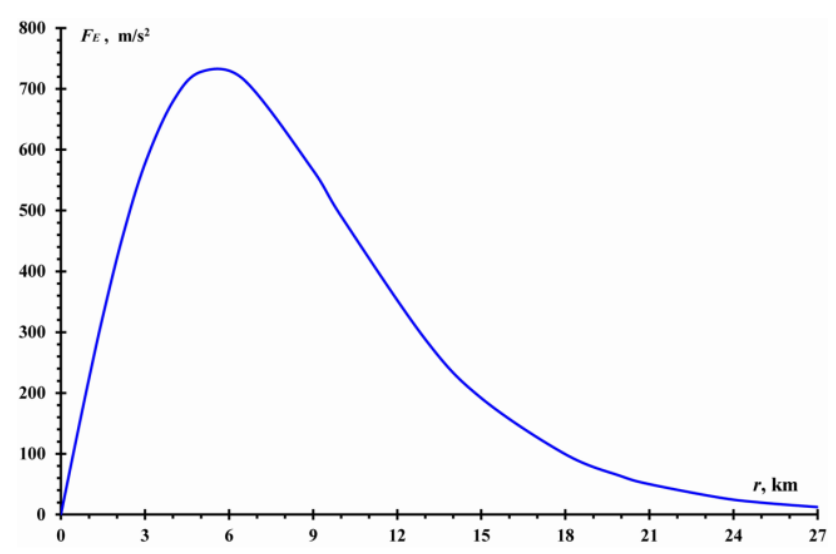

Figure 11. Computation of the vortex force for the violent tornado (Figure 8 ) realized by Eq. (40)
The eddy force enters into the Gromeka-Lamb vectorial equation

$$
\frac{\partial v}{\partial t}+\operatorname{grad}\left(\frac{v^{2}}{2}\right)-[v \times \operatorname{rot} v]=-\frac{1}{\rho} \operatorname{grad} p+\eta \Delta v,
$$

which follow from the Naiver-Stokes equation (Lamb, 1945; Vasil'yev, 1958).

If the eddy force is absent $\left(F_{E}=0\right)$, then Eq. (39) implies the equation

$$
\frac{d v}{v}=-\frac{d r}{r}
$$

This solution is the law of hyperbolic wind-velocity abatement $v=v_{0} \frac{r_{0}}{r}$, which corresponds to the Ranque eddy in an ideal fluid without friction (Vasil'yev, 1958; Saffman, 2000). We can see from Figure 11 that $F_{E} \neq 0$, i.e., the Ranque eddy does not occur in our case, because the air motion in tornado passes under the presence of turbulent friction. The maximum value of $F_{E-\max }=740 \mathrm{~m} / \mathrm{s}^{2}$ is attainable at the inner boundary of the "wall of the hurricane". Multiplying $F_{E-\max }$ by $\rho=1.3 \mathrm{~kg} / \mathrm{m}^{3}$ we find $\Phi \approx 962 \mathrm{n} / \mathrm{m}^{3}$. On the house with a volume $10^{3} \mathrm{~m}^{3}$ tornado acts with a force $962 \cdot 10^{3} \mathrm{n}$. This force is equal to weight of a mass 98 metric tons. To reduce this wind force building(s) should have the streamline aerodynamic form. Damage to buildings could be totally avoided if the buildings were located underground.

It is necessary to underline that the presented methodology may be flexibly modified for investigation of other atmospheric and solid Earth phenomena.

\section{Conclusions}

In this work, a novel physical-mathematical model of creating the violent tornadoes in troposphere (as result of the tidal gravity wave influence), has been developed. In the years of increasing gravity activity within the Earth-Moon-Sun system, is necessary to expect an increment of number and intensity of the squall storms which represent strong tidal nonlinear waves in troposphere. Therefore, at that time an increased number of the violent tornadoes should be observed. The present investigation enabled to establish an analytical connection between the numbers of tornadoes per year with the tidal forces, which was found earlier as result of statistical analysis of the observed data. It should be noted that this approach may be effectively applied to studying other environmental effects associated with the Moon-Sun activity. 


\section{REFERENCES}

Alizadeh A.A., Guliyev I.S., Kadirov F.A., Eppelbaum L.V. Geosciences in Azerbaijan. V. II - Economic minerals and applied geophysics. Springer. Heidelberg - N.Y., 2017, 340 p.

Arsen'yev S.A. Dynamics of shelf water. Moscow State University. Moscow, 1989, 96 p. (in Russian).

Arsen'yev S.A. Irregular Earth's rotation and dynamics of the gas-liquid geospheres. Doklady of the Russian Academy of Sciences, V. 343, № 2, 1995, pp. 251-254.

Arsen'yev S.A. About origin of the synoptic variability in ocean Moscow University Physics Bulletin, V. 39, № 6 (Alerton Press, Inc., USA), 1998, pp. 40-44.

Arsen'yev S.A. Mathematical modeling of tornadoes and squall storms. Geosciences Frontiers, V. 2, № 2, 2011, pp. 215-221.

Arsen'yev S.A., Nikolaevskiy V.N., Shelkovnikov N.K. Eddy instability and initiation of tornado. Moscow University Physics Bulletin, V. 41, № 1 (Alerton Press, Inc., USA), 2000, p. 50-54.

Arsen'yev S.A., Nikolaevskiy V.N. Modelling of tornadoes by turbulence theory with Eddy Angular Momentum. Trans. of the SIAM Conference on Mathematical and Computational Sciences. Issue in the Geosci. Boulder, CO USA, 2001, p. 13.

Arsen'yev S.A., Gubar A.Yu., Nikolaevskiy V.N. Selforganization of tornado and hurricanes in atmospheric currents with mesoscale eddies. Doklady of the Russian Academy of Sciences, V. 396, № 4, 2004, pp. 588-593.

Arsen'yev S.A., Babkin V.A., Gubar A.Yu., Nikolaevskiy V.N Theory of mesoscale turbulence. Eddies of atmosphere and ocean. Inst. of Computer Sciences, Regular and Chaotic Dynamics. Moscow-Izhevsk, 2010, pp. 365-371 (in Russian).

Bluestein H.B. A history of severe-storm-intercept field programs. Weather and Forecasting, V. 14, 1999, pp. 558-577.

Belyakov A.S., Lavrov A.S., Nikolaev A.V. Seismoacoustic emission, earthquakes, and Lunar-Solar tides. Doklady Earth Sciences (Springer), V. 420, № 4, 2008, pp. 670-671.

Burgess D.W., Magsig M.A., Wurman J., Dowell D.C., Richardson Y. Radar observations of the 3 May 1999 Oklahoma City Tornado. Weather and Forecasting, V. 17, 2002, pp. 456-471.

Chizevsky A.L. The Earth echo of the Sun's storms. Mysl' Publ. Moscow, 1976, 367 p. (in Russian).

De Jager C. Structure and dynamics of the solar atmosphere. Springer-Verlag. Berlin- Gottingen-Heidelberg, 1959, 362 p.

Doswell C.A., Burgess D.W. Tornadoes and tornadic storms: A review of conceptual models. In: The Tornado: Its Structure, Dynamics, Prediction, and Hazards. Geophys. Monogr. V. 79, Amer. Geophys. Union, 1993, pp. 161-172.

Dikiy L.A. The theory of oscillations of the Earth's atmosphere. Gidrometeoizdat. Leningrad, 1969, 196 p. (in Russian).

Drton M., Marzban C., Guttorp P., Schaefer J.T. A Markov chain model of tornadic activity. American Meteorological Society, V. 131, № 12, 2003, pp. 2941-2953.

Eppelbaum L.V. Non-stochastic long-term prediction model for US tornado level. Natural Hazards, V. 69, 2013, pp. 22692278.

Eppelbaum L.V. Potential geophysical fields: geological and environmental applications. Elsevier. Amsterdam, 2019, $551 \mathrm{p}$.

Eppelbaum L., Isakov A. Implementation of the geo-correlation methodology for predictability of catastrophic weather events: long-term US tornado season and shortterm hurricanes. Environmental Earth Sciences, V. 74, 2015, pp. 3371-3383.

Eppelbaum L.V., Kardashov V.R. Analysis of strongly nonlinear processes in geophysics. In: Proceed. of the Chapman Conference on Exploration Geodynamics. Moresi, L. and Mül-

\section{ЛИТЕРАТУРА}

Alizadeh A.M., Guliyev I.S., Kadirov F.A., Eppelbaum L.V. Geosciences in Azerbaijan. V. II - Economic minerals and applied geophysics. Springer. Heidelberg - N.Y., 2017, 340 p.

Arsen'yev S.A. Irregular Earth's rotation and dynamics of the gas-liquid geospheres. Doklady of the Russian Academy of Sciences, V. 343, № 2, 1995, pp. 251-254.

Arsen'yev S.A. About origin of the synoptic variability in ocean. Moscow University Physics Bulletin, V. 39, № 6 (Alerton Press, Inc., USA), 1998, pp. 40-44.

Arsen'yev S.A. Mathematical modeling of tornadoes and squall storms. Geosciences Frontiers, V. 2, № 2, 2011, pp. 215-221.

Arsen'yev S.A., Nikolaevskiy V.N., Shelkovnikov N.K. Eddy instability and initiation of tornado. Moscow University Physics Bulletin, V. 41, № 1 (Alerton Press, Inc., USA), 2000, p. 50-54.

Arsen'yev S.A., Nikolaevskiy V.N. Modelling of tornadoes by turbulence theory with Eddy Angular Momentum. Trans. of the SIAM Conference on Mathematical and Computational Sciences. Issue in the Geosci. Boulder, CO USA, 2001, p. 13.

Arsen'yev S.A., Gubar A.Yu., Nikolaevskiy V.N. Selforganization of tornado and hurricanes in atmospheric currents with mesoscale eddies. Doklady of the Russian Academy of Sciences, V. 396, № 4, 2004, pp. 588-593.

Bluestein H.B. A history of severe-storm-intercept field programs. Weather and Forecasting, V. 14, 1999, pp. 558-577.

Belyakov A.S., Lavrov A.S., Nikolaev A.V. Seismoacoustic emission, earthquakes, and Lunar-Solar tides. Doklady Earth Sciences (Springer), V. 420, № 4, 2008, pp. 670-671.

Burgess D.W., Magsig M.A., Wurman J., Dowell D.C., Richardson Y. Radar observations of the 3 May 1999 Oklahoma City Tornado. Weather and Forecasting, V. 17, 2002, pp. 456-471.

De Jager C. Structure and dynamics of the solar atmosphere. Springer-Verlag. Berlin- Gottingen-Heidelberg, 1959, 362 p.

Doswell C.A., Burgess D.W. Tornadoes and tornadic storms: A review of conceptual models. In: The Tornado: Its Structure, Dynamics, Prediction, and Hazards. Geophys. Monogr. V. 79, Amer. Geophys. Union, 1993, pp. 161-172.

Drton M., Marzban C., Guttorp P., Schaefer J.T. A Markov chain model of tornadic activity. American Meteorological Society, V. 131, № 12, 2003, pp. 2941-2953.

Eppelbaum L.V. Non-stochastic long-term prediction model for US tornado level. Natural Hazards, V. 69, 2013, pp. 22692278 .

Eppelbaum L.V. Potential geophysical fields: geological and environmental applications. Elsevier. Amsterdam, 2019, 551 p.

Eppelbaum L., Isakov A. Implementation of the geo-correlation methodology for predictability of catastrophic weather events: long-term US tornado season and short-term hurricanes. Environmental Earth Sciences, V. 74, 2015, pp. 3371-3383.

Eppelbaum L.V., Kardashov V.R. Analysis of strongly nonlinear processes in geophysics. In: Proceed. of the Chapman Conference on Exploration Geodynamics. Moresi, L. and Müller, D. (eds.). Dunsborough, Western Australia, 2001, pp. 43-44.

Garner J.M. Environments of significant tornadoes occurring within the warm sector versus those occurring along surface baroclinic boundaries. Electronic Jour. of Severe Storms Meteor., V. 7, № 5, 2012, pp. 1-28.

Gill A.E. Atmosphere-ocean dynamics. Academic Press. N.Y. London, 1982, $644 \mathrm{p}$.

Gray L.J., Beer J., Geller M., Haigh J.D., Lockwood M., Matthes K., Cubasch U., Fleitmann D., Harrison G., Hood L., Luterbacher J., Meehl G.A., Shindell D., van Geel B., White W. Solar influences on climate. Review of Geophys- 


\section{Geology and geophysics}

ler, D. (eds.). Dunsborough, Western Australia, 2001, pp. 43-44.

Gadirov V.G. Natural alterations in oil output. Facts and hypotheses. Geophysics: News in Azerbaijan, № 3, 2001, pp. 21-24 (in Azerbaijani).

Garner J.M. Environments of significant tornadoes occurring within the warm sector versus those occurring along surface baroclinic boundaries. Electronic Jour. of Severe Storms Meteor., V. 7, № 5, 2012, pp. 1-28.

Gill A.E. Atmosphere-ocean dynamics. Academic Press. N.Y. London, 1982, $644 \mathrm{p}$.

Gray L.J., Beer J., Geller M., Haigh J.D., Lockwood M., Matthes K., Cubasch U., Fleitmann D., Harrison G., Hood L., Luterbacher J., Meehl G.A., Shindell D., van Geel B., White W. Solar influences on climate. Review of Geophysics, V. 50, 2012, pp. 1-53. RG1006, DOI: 10.1029/ 2011 RG000387.

Hirth B.D., Schroeder J.L., Weiss C.C. Surface analysis of the rear-flank downdraft outflow in two tornadic supercells. Monthly Weather Review, V. 136, 2008, pp. 2344-2363.

Huang Z., Fan X., Cai L., Shi S.Q. Tornado hazard for structural engineering. Natural Hazards, V. 83, 2016, pp. 1821-1842.

Kardashov V.R., Eppelbaum L.V. Mathematical models of strongly nonlinear geophysical phenomena. Trans. of the $5^{\text {th }}$ Europ. Conf. of Mathematicians. Amsterdam, The Netherlands, 2008, 2 p.

Kardashov V.R., Eppelbaum L.V., Vasilyev O.V. The role of nonlinear source terms in geophysics. Geophysical Research Letters, V. 27, № 14, 2000, pp. 2069-2073.

Khrgian A.H. Physics of atmosphere. Gidrometeoizdat. Leningrad, 1978, 532 p. (in Russian).

Khromov S.P., Mamontova L.N. Meteorological dictionary. Gidrometeoizdat. Leningrad, 1974, 567 p. (in Russian).

Kotelnikov V.A. On the carrying capacity of the ether and wire in telecommunications. Trans. of the First All-Union Conf on Problems of Communic. Izd. Upr. Svyazi RKKA. Moscow, 1933 (in Russian).

Laing A. Mesoscale convective systems. In: Encyclopedia of Atmospheric Sciences. North G.R., Pyle J.A., Zhang F., (eds.) Elsevier. The Netherlands, $2^{\text {nd }}$ Edition, 2015, pp. 339-354.

Lamb H. Hydrodynamics. Dover. USA, 1945, 760 p.

Landscheidt $\mathrm{T}$. The cosmic function of the golden section. In: HSG: Sterne, Mond und Kometen. Bremen und die Astronomie. Richter, P.H., (ed.) Verlag H.M. Hauschild, Bremen, 1995, pp. 240-276 (in German).

Landscheidt T. Solar activity of EL Nino and LA Nina. 2013. http://www.john-daly.com/sun-enso/sun-enso.htm.

Lorenz E.N. The interaction between a mean flow and random disturbances. Tellus, V. 21, № 3, 1953, pp. 289-307.

Markowski P., Richardson Y. What we know and don't know about tornado formation. Physics Today, V. 67, № 9, 2014, pp. 25-31.

Marshall T.P. Tornado damage survey at Moore, Oklahoma. Weather Forecasting, V. 17, 2002, pp. 582-598.

Monastersky R. Oklahoma tornado sets wind records. Science News, V. 155, № 2, 1999, pp. 308-309.

Nalivkin D.V. Hurricanes, storms and tornadoes. Nauka. Leningrad, 1969, 487 p. (in Russian).

Naylor J., Gilmore M.S. Environmental factors influential to the duration and intensity of tornadoes in simulated supercells. Geophysical Research Letters, V. 39, 2012, pp. 1-5. L17802. DOI: 10.1029/2012GL053041.

Nikolaevskiy V.N. Angular momentum in geophysical turbulence: continuum. Spatial averaging method. Kluwer (Springer). Dordrecht, 2003, 244 p.

Nyquist $H$. Certain topics in telegraph transmission theory. Trans. AIEE, V. 47, 1928, pp. 617-644. ics, V. 50, 2012, pp. 1-53. RG1006, DOI: 10.1029/ 2011 RG000387.

Hirth B.D., Schroeder J.L., Weiss C.C. Surface analysis of the rear-flank downdraft outflow in two tornadic supercells. Monthly Weather Review, V. 136, 2008, pp. 2344-2363.

Huang Z., Fan X., Cai L., Shi S.Q. Tornado hazard for structural engineering. Natural Hazards, V. 83, 2016, pp. 1821-1842.

Kardashov V.R., Eppelbaum L.V. Mathematical models of strongly nonlinear geophysical phenomena. Trans. of the $5^{\text {th }}$ Europ. Conf. of Mathematicians. Amsterdam, The Netherlands, 2008, $2 \mathrm{p}$

Kardashov V.R., Eppelbaum L.V., Vasilyev O.V. The role of nonlinear source terms in geophysics. Geophysical Research Letters, V. 27, № 14, 2000, pp. 2069-2073.

Laing A. Mesoscale convective systems. In: Encyclopedia of Atmospheric Sciences. North G.R., Pyle J.A., Zhang F., (eds.). Elsevier. The Netherlands, $2^{\text {nd }}$ Edition, 2015, pp. 339-354.

Lamb H. Hydrodynamics. Dover. USA, 1945, 760 p.

Landscheidt T. Solar activity of EL Nino and LA Nina. 2013. http://www.john-daly.com/sun-enso/sun-enso.htm.

Lorenz E.N. The interaction between a mean flow and random disturbances. Tellus, V. 21, № 3, 1953, pp. 289-307.

Markowski P., Richardson Y. What we know and don't know about tornado formation. Physics Today, V. 67, № 9, 2014, pp. 25-31.

Marshall T.P. Tornado damage survey at Moore, Oklahoma. Weather Forecasting, V. 17, 2002, pp. 582-598.

Monastersky R. Oklahoma tornado sets wind records. Science News, V. 155, № 2, 1999, pp. 308-309.

Naylor J., Gilmore M.S. Environmental factors influential to the duration and intensity of tornadoes in simulated supercells. Geophysical Research Letters, V. 39, 2012, pp. 1-5. L17802. DOI: 10.1029/2012GL053041.

Nikolaevskiy V.N. Angular momentum in geophysical turbulence: continuum. Spatial averaging method. Kluwer (Springer). Dordrecht, 2003, 244 p.

Nyquist H. Certain topics in telegraph transmission theory. Trans. AIEE, V. 47, 1928, pp. 617-644.

Paulikas M.J., Schmidlin T.W. US tornado fatalities in motor vehicles (1991-2015). Natural Hazards, V. 87, 2017, pp. 121-143.

Pedlosky J. Geophysical fluid dynamics. Springer-Verlag. N.Y. Heidelberg - Berlin, 1992, $710 \mathrm{p}$.

Riguzzi F., Panza G., Varga P., Doglioni K. Can Earth's rotation and tidal despinning drive plate tectonics? Tectonophysics, V. 484,2010 , pp. 60-73.

Scafetta N., West B.J. Is climate sensitive to solar variability? Physics Today, March 2008, pp. 50-51.

Snow J.T. The tornado. Scientific American, V. 250, 1984, pp. 86-97.

Smith B., Katz R.W. US billion-dollar weather and climate disasters: data sources, trends, accuracy and biases. Natural Hazards, V. 67, 2013, pp. 387-410.

Tanaka, S., Ontake, M. and Sato, H. Tidal triggering of earthquakes in Japan related to the regional tectonic stress. Earth, Planet, Space, V. 56, 2004, pp. 511-515.

Vasil'yev O.F. Mechanics of the spiral and circulatory flows. A foundation. Gostechizdat. Moscow - Leningrad, 1958, 145 p. (in Russian).

Winn W.P., Hunyady S.J., Aulich G.D. Pressure at the ground in a large tornado. Jour. of Geophysical Research, V. 104 (D18), 1999, pp. 22067-22082.

Wurman J., Dowell D., Richardson Y., Markowski P., Ramussen E., Burgess D., Wicker L., Bluestein H.B. The second verification of the origins of rotation in tornadoes experiment Vortex2. Bull. of the American Meteorological Society, V. 8, 2012, pp. 1147-1170. 
Paulikas M.J., Schmidlin T.W. US tornado fatalities in motor vehicles (1991-2015). Natural Hazards, V. 87, 2017, pp. 121-143.

Pedlosky J. Geophysical fluid dynamics. Springer-Verlag. N.Y. Heidelberg - Berlin, 1992, $710 \mathrm{p}$.

Riguzzi F., Panza G., Varga P., Doglioni K. Can Earth's rotation and tidal despinning drive plate tectonics? Tectonophysics, V. 484, 2010, pp. 60-73.

Saffmen P.G. Dynamics of eddies. Nauchny mir. Moscow, 2000, 376 p. (in Russian).

Scafetta N., West B.J. Is climate sensitive to solar variability? Physics Today, March 2008, pp. 50-51.

Sidorenkov N.S. Atmospheric processes and the Earth's evolution. Gidrometeoizdat. St. Petersburg, 2002, 365 p. (in Russian).

Snow J.T. The tornado. Scientific American, V. 250, 1984, pp. 86-97.

Smith B., Katz R.W. US billion-dollar weather and climate disasters: data sources, trends, accuracy and biases. Natural Hazards, V. 67, 2013, pp. 387-410.

Tanaka S., Ontake M. and Sato H. Tidal triggering of earthquakes in Japan related to the regional tectonic stress. Earth, Planet, Space, V. 56, 2004, pp. 511-515.

Vasil'yev O.F. Mechanics of the spiral and circulatory flows. A foundation. Gostechizdat. Moscow- Leningrad, 1958, 145 p. (in Russian).

Winn W.P., Hunyady S.J., Aulich G.D. Pressure at the ground in a large tornado. Jour. of Geophysical Research, V. 104 (D18), 1999, pp. 22067-22082.

Wurman J., Dowell D., Richardson Y., Markowski P., Ramussen E., Burgess D., Wicker L., Bluestein H.B. The second verification of the origins of rotation in tornadoes experiment Vortex2. Bull. of the American Meteorological Society, V. 8, 2012, pp. 1147-1170.

Wurman J., Gill S. Fine scale radar observation of the Dimmit, Texas (2 June 1995) Tornado. Monthly Weather Review, V. 128, № 7, 2000, pp. 2135-2164.
Wurman J., Gill S. Fine scale radar observation of the Dimmit, Texas (2 June 1995) Tornado. Monthly Weather Review, V. 128, № 7, 2000, pp. 2135-2164.

Landscheidt T. Die kosmische Function des Goldenen Schnitts. In: HSG: Sterne, Mond und Kometen. Bremen und die Astronomie. Richter, P.H., (ed.) Verlag H.M. Hauschild, Bremen, 1995, pp. 240-276.

Арсеньев С.А. Динамика вод шельфов. Московский Государственный Университет. Москва, 1989, 96 с.

Арсеньев С.А., Бабкин В.А., Губарь А.Ю., Николаевский В.Н. Теория мезомасштабной турбулентности. Вихри атмосферы и океана. Ин-т компьютерных наук, регулярной и хаотической динамики. Москва-Ижевск, 2010, с. 365-371.

Васильев О.Ф. Основы механики винтовых и циркуляционных потоков. Гостехиздат. Москва-Ленинград, 1958, 145 с.

Дикий Л.А. Теория колебаний земной атмосферы. Гидрометеоиздат. Ленинград, 1969, 196 с.

Котельников В.А. О пропускной способности эфира и проволоки в электросвязи. Материалы к I Всесоюзному съезду по вопросам технической реконструкции дела связи и развития слаботочной промышленности. Издательство Управления Связи РККА. Москва, 1933.

Наливкин Д.В. Ураганы, бури и смерчи. Наука. Ленинград, 1969,487 c.

Сидоренков Н.С. Атмосферные процессы и вращение Земли. Гидрометеоиздат. Санкт-Петербург, 2002, 365 с.

Сэффмэн Ф.Дж. Динамика вихрей. Научный мир. Москва, $2000,376 \mathrm{c}$.

Хиргиан А.Н. Физика атмосферы. Гидрометеоиздат. Ленинград, 1978, $532 \mathrm{c}$

Хромов С.П., Мамонтова Л.Н. Метеорологический словарь. Гидрометеоиздат. Ленинград, 1974, 567 с.

Чижевский А.Л. Земное эхо солнечных бурь. Мысль. Москва, 1976, 376 с.

Qədirov V.G. Neft hasilatında təbii dəyişikliklər. Faktlar və fərziyyələr. Geofizika: Azerbaycanda xəbərlər, № 3, 2001, pp. 21-24.

\title{
ОПАСНЫЕ АТМОСФЕРНЫЕ ЯВЛЕНИЯ: НОВЫЙ ФИЗИКО-МАТЕМАТИЧЕСКИЙ ПОДХОД
}

\author{
Арсеньев С.А. ${ }^{1}$, Эппельбаум Л.В. ${ }^{2}$, Ермакова Н.Н. ${ }^{3}$ \\ ${ }^{1}$ Отделение планетарной геофизики и геодинамики Института Физики Земли им. О.Ю. Шмидта, \\ Российская Академия Наук \\ 123995, Россия, Москва, Большая Грузинская ул., 10: Arsy7@таil.ru \\ ${ }^{2}$ Отделение Наук о Земле, Факультет точных наук им. Раймонда и Беверли Саклер, Тель-Авивский Университет \\ 6997801, Израиль, Тель-Авив, Рамат Авив: levap@ post.tau.ac.il \\ ${ }^{3}$ Отделение химии, Факультет точных наук им. Раймонда и Беверли Саклер, Тель-Авивский Университет \\ 6997801, Израиль, Тель-Авив, Рамат Aвив: ermakov@post.tau.ac.il
}

Резюме. В последнее время достигнут значительный прогресс в долгосрочном прогнозе таких опасных атмосферных явлений, как катастрофические и сильные торнадо (уровень EF3-EF5). Л. Эппельбаумом в 2013 году разработан нестохастический долговременный метод предсказания на основе использования метода долгосрочного прогнозирования с использованием теории распознавания образов и Фурье-анализа. Им выявлена тесная корреляция между общим количеством торнадо в год и параметрами гравитационной системы, продуцирующей приливные эффекты. Однако физический смысл этой связи оставался нераскрытым. В представленной работе предлагается новая физико-математическая модель, объясняющая процесс возникновения мощных торнадо. Модель включает два главных этапа. Вначале гравитационные силы и ураганные ветры в верхней тропосфере образуют нелинейные длинные волны в нижней тропосфере. Затем возникают штормовые ветры в верхней тропосфере (при проникновении холодных масс воздуха в теплых районах), связанные обычно с быстрыми синоптическими циклонами, несущими грозовую облачность и дожди. Возникающие гравитационные нелинейные волны устремляются со скоростью приливных волн $V=(\mathrm{gH})^{1 / 2}$ вдоль инверсии субоблака. После этого гравитационные волны падают (и поглощаются) суперячейкой грозы, которая уже сформировалась внутри холодного атмосферного фронта. В результате адаптации метеорологического поля давление внутри грозовой суперячейки уменьшается, вращение ветра усиливается, что порождает сильный торнадо. Различные примеры иллюстрируют применимость разработанного подхода, причем теоретические результаты хорошо согласуются с практическими наблюдениями. Предложенная новая физико-математическая методология может быть концептуально применена для анализа других явлений, происходящих в атмосфере Земли.

Ключевые слова: торнадо, длинные приливные гравитационные волны, гравитационная система Земля-Луна-Солнце, солитон, опасные атмосферные феномены 


\title{
TəHLÜKӘLI ATMOSFER HADISכLəRI: YENI FIZIKII-RIYAZI YANAŞMA
}

\author{
Arsenyev S.A. ${ }^{1}$, Eppelbaum L.V. ${ }^{2}$, Yermakova N.N. ${ }^{3}$ \\ ${ }^{1}$ Rusiya Elmlar Akademiyası O.Y.Şmidt adına Yer Fizikası İnstitutunun Planetar geofizika va geodinamika bölməsi, \\ 123995, Rusiya, Moskva şəh., Bolşaya Qruzinskaya küç., 10: Arsy7@mail.ru \\ ${ }^{2}$ Geoelmlar maktəbi, Reymond va Beverli Sakler adına Daqiq Elmlar fakültəsi, Təl-Oviv Universiteti \\ 6997801, Israil,Tal-Aviv, Ramat Aviv: levap@post.tau.ac.il \\ ${ }^{3}$ Kimya maktabi, Reymond va Beverli Sakler adına Daqiq Elmlar fakültasi, Tal-Әviv Universiteti \\ 6997801, Israil, Tal-Aviv, Ramat Aviv: ermakov@post.tau.ac.il
}

\begin{abstract}
Xülasə. Son vaxtlar fəlakətli və güclü tornadolar (səviyyə EF3-EF5) kimi təhlükəli atmosfer hadisələrinin uzunmüddətli proqnozunda mühüm irəliləyişə nail olunmuşdur. Simaların tapılması nəzəriyyəsindən və Furye analizdən istifadə etməklə uzunmüddətli proqnozlaşdırma üsulundan istifadə əsasında L.V.Eppelbaum (2013) geyri-stoxastik uzunmüddətli öncədən xəbərvermə üsulunu işləmişdir. O, il ərzində tornadonun ümumi miqdarı və qabarma effektləri yaradan qravitasiya sisteminin parametrləri əsasında sıx korrelyasiya aşkar etmişdir. Lakin bu əlaqənin fiziki mənası açılmamış qalmışdır. Təqdim olunan işdə biz güclü tornadoların yaranmasını izah edən yeni fiziki-riyazi model təklif edirik. Təqdim olunan model iki başlıca etapdan ibarətdir. Başlanğıcda yuxarı troposferdə qravitasiya qüvvələri və çox güclü küləklər aşağı troposferdə, adətən tufanlı dumanlıq və yağış daşıyan sürətli sinoptik siklonlarla bağlı olan, qeyri-xətti uzun dalğalar əmələ gətirir. Sonra, yuxarı troposferdə firtına küləkləri yaranır (isti rayonlarda havanın soyuq kütlələri soxulanda). Yaranan qravitasiya qeyri-xətti dalğaları subdumanlığın inversiyası boyunca qabarma dalğalarının sürəti ilə $\mathrm{V}=(\mathrm{gH})^{1 / 2}$ cumur (hücum edir). Bundan sonra qravitasiya dalğaları soyuq atmosfer cəbhəsinin daxilində formalaşan tufanın superözəyi ilə udulur. Meteoroloji sahənin adaptasiyası nəticəsində tufan superözəyinin daxilində təzyiq azalır, küləyin firlanması şiddətlənir və bu da güclü tornado yaradır. Müxtəlif nümunələr işlənilmiş yanaşmanın tətbiq edilməsini əks etdirir, həm də nəzəri nəticələr praktiki müşahidələrlə yaxşı uzlaşır. Təklif olunan yeni fiziki-riyazi metodologiya Yer atmosferində baş verən digər hadisələrin təhlili üçün konseptual tətbiq oluna bilər.

Açar sözlar: tornado, uzun qabarma qravitasiya dalğaları, Yer-Ay-Günəş qravitasiya sistemi, soliton, təhlükali atmosfer fenomenləri
\end{abstract}

